\title{
The construction of applied undergraduate colleges and universities sports club teaching model research
}

\author{
Fanwei Meng \\ Changchun University of science and technology, Changchun 130000, China. \\ 13742883@qq.com
}

Key words: Application type undergraduate school, Sports club, teaching mode, build.

\begin{abstract}
This text USES the method of documents and materials, questionnaire investigation, expert interview method, mathematical statistics and logic analysis to the present stage our country the development of university sports club teaching model and the analysis of existing problems, and on this basis, created by changchun institute of science and technology, different from traditional sports club, according to the boys and girls are most interested in the project to make the teaching mode of the divide into classes teaching, to overcome some of the colleges and universities sports clubs for students free press inequality and a series of problems; And the exchange of each class exercise program, but also different from the traditional sports teaching of a major bright spot, more comprehensive.
\end{abstract}

\section{Introduction}

Colleges and universities sports club teaching is a kind of new teaching mode, in our country sports club as a new teaching organization form is becoming increasingly popular, college sports clubs in adapt to the development of education abroad at the same time, also reflected the development direction of college PE teaching reform, advancing with The Times. The undergraduate education is different from the academic undergraduate institutions in the training of specification and mode, and should be applied as the "gist" to build the curriculum system. The club teaching is the effective channel to train the students' practical application. This paper studies how to construct the teaching mode of college sports club in our country at the present stage, which is intended to provide reasonable suggestion for the formulation of the training plan for applied talents.

\section{The present situation of the development of the teaching mode of college sports club in China}

(1) The meaning of the teaching of university sports club.

The teaching of college sports club is formulated according to the talents training goal of colleges and universities, the requirements of the college students of sports teaching, to cultivate and establish students' consciousness of lifelong physical exercise, master the item 1, 2 be engaged in sports skills and methods, give full play to the individual sports talents, interests and hobbies, lay good foundation for the lifelong physical exercise. Club teaching in physical education teaching organization form, students according to their interests, hobbies and sports, the freedom to choose a class is not subject to time constraints, can according to own actual have class at any one time to go to their chosen course. The course adopts the teaching method of heuristic learning which is the main body of the student, and has the strict examination standard and the teaching plan, is a new kind of teaching mode. Sports clubs, in general, is to achieve a major change in student-centered teaching, it emphasizes that learning combined with exercise class inside and outside, attention to the cultivation of physical culture quality, the social sports, school sports into is able to develop the students' physical quality, at present our country ordinary undergraduate course colleges and universities are more a kind of teaching mode.

(2) The advantages of teaching in university sports club. 
Traditional sports teaching mode has a big disadvantage compared to the sports club teaching, mainly manifested in the following aspects: the sports club teaching pay more attention to students' individual character development, changed the traditional educational and bored by the flatness of the physical education teaching, can greatly satisfy the requirement of the student individuality development, fully mobilize the enthusiasm of the students in class; Inspire students to use their wisdom and ability to learn and exercise, students participate in teaching activities reflect a subject consciousness of sports value, at the same time, arouse the enthusiasm of the teachers' teaching; Sports club teaching mode of teaching contents and sports is given priority to with richness and diversity, can fully meet the needs of students of physical education, multiple choices, expanding students' activity space; Sports club teaching was conducted on the premise of students choose teachers, make the sports teaching the introduction of competition mechanism, enhance teachers' sense of responsibility and urgency, give full play to the teacher's subjective initiative.

\section{The requirements for the establishment of a sports club are established by the undergrad uate colleges and universities}

(1) Hardware and faculty.

Sports club teaching mode of teaching contents and sports is given priority to with richness and diversity, which inevitably to the university sports venues and equipment facilities put forward higher requirements, the location equipment facilities is to guarantee the teaching smoothly, the basis of investigation, according to the results of the national university sports venues accounted for only $5 \%$ of standard of colleges and universities. Applied undergraduate colleges and universities are generally new colleges and universities, and the construction of facilities for sports facilities is high, the project is more comprehensive and the quality level is higher. So the applied undergraduate colleges and universities sports club teaching the most basic conditions, there is a more adequate to meet 16 sports project location equipment.

According to the latest survey results show that the emerging sports and small ball project general lack of teachers, is common across professional teachers, and teachers vary in the degree of specialization, have great influence on the development of the club. Student options are still concentrated in basketball, football, aerobics and badminton. And some new projects, such as tennis, swimming, dancing, and women's self-defense, are not only restricted by venue facilities, but also by teachers. Therefore, colleges and universities must strengthen the construction of teachers team, using irfpa "from within" policy mechanisms, can adapt to the needs of the development of college sports, applied undergraduate colleges and universities generally its short history, hiring teachers should be to each according to his need, in order to meet the needs of the sports club teaching.

(2) the student's foundation and interest.

Sports club is teaching students according to their own interests, and based the freedom to choose sports programs, the classroom to have a class, fully highlights the subjectivity of the students, but in the actual teaching process is a project alternative number too much, caused by uneven student newspaper item classes, class, and a series of problems, resulting in "passive options", and the problem of gender tendency options which conflict with the purpose of the sports club teaching. The literature shows that the students' physical qualities are better than those of academic institutions, and the basis of the teaching of the club is better

\section{The innovation point of the teaching model of applied undergraduate sports club}

(1)Scientific building club teaching modular combination.

According to the results of national university students' sports interest survey, set up the project, the results of the survey shows that men are most interested in the first five items of basketball, football, table tennis, badminton, martial arts; The first five items that girls are most interested in are aerobics, form, sports dancing, table tennis and badminton. This study is based on the fact that men have four 
sports teaching clubs, such as basketball, football, tennis and martial arts. Women open table tennis, badminton, aerobics, volleyball four sports teaching clubs.

(2) to solve many problems in the teaching of traditional college sports clubs.

The difference between men's and women's classes and women's programs is one of the great innovations of this study. According to the differences of male and female physiological structure and college students interested in the results of the survey scientific reasoning, on the project Settings to avoid the traditional exercise uneven due to mixed teaching, affect the enthusiasm of students to practice, is not conducive to project and so on. Single-sex classes set different project in class, thus avoids many disadvantages of traditional teaching of the club, so as to maximize the teaching effect of physical education club. Single-sex classes in class, so that each class exercise program exchange, a more reasonable body parts of the scientific development of the students, improve the students' interest, to make students more actively practicing, the optimum effect of exercise.

The students' freedom newspaper will result in the disparity in the number of items in the project, which will result in the difficulty of the division, the difficulty of the course and the management. The sports teaching club has avoided the "trilemma" by setting up different projects for the male and female students.

According to the project construction of sports facilities, special physical education teachers to provide more targeted, sports club teaching facilities and professional teachers put forward higher request, according to create "six goals, a wu, a fuck" eight club teaching request, has the standard facilities and special teachers.

(3) increase cardiopulmonary function practice, and the course system is more scientific.

In ten minutes before the end of each class to increase run 1000 meters ( 800 meters) practice to enhance the students' cardiopulmonary function, it has to do with 2014 issued by the ministry of education of the higher school sports work standard requirements, with clear requirements of the standard of each class to improve students' cardiopulmonary function exercise content shall not be less than $30 \%$, and will reflect the students' cardiopulmonary function test included in the final grade.

\section{The policy}

Applied undergraduate colleges and universities in sports venues, sports teachers' selection and students' physical quality and sports interests, etc., have build a new sports club teaching mode, summary of club teaching experience and problem, the following measures should be taken.

(1) continue to cultivate and strengthen the interest of students, through the teaching of the sports club, the students have the skills and methods of 1-2 lifelong sports training.

(2) to make students well in the habit of taking part in physical exercise.

(3) special teachers should constantly improve their special skills and teaching level.

(4) emphasize the extension in and out of the course and improve the students' skills

\section{Acknowledgments}

The advanced education institute in jilin province will be the subject of high education research in 2017. 《The study of the teaching mode of applied undergraduate sports club》.Project approval number: JGJX2017D278

\section{References}

[1]. Yang qin, li naijun. The research and practice of the teaching mode of the local undergraduate sports club [J]. Sports technology, 2016, (06) : 117-118.

[2]. liu bo. The business development and countermeasures of volleyball club of China [D]. Shandong university, 2013. 
[3]. Zhang Chongying chien-hsiung chang, Jiang Yuelan, hong-wei sun. Independent colleges to carry out the sports option class teaching mode of [J]. Journal of shaolin and tai chi (zhongzhou sports), 2012, (6) : 64-68.

[4]. qin yingjie. The present situation and countermeasures of the sports teaching club of the normal university in shaanxi province [D].yan 'an university, 2012.

[5]. zhang hongliang. The method and game analysis [D]. Beijing sports university, 2012.

[6]. wang yu-gang. The development of the development strategy of middle school sports club in changchun city. [D].northeast normal university, 2012.

[7]. Yang hong. The present situation and development mode of university sports club in jilin province [D].yanbian university, 2010.

[8]. xu haifeng. The present situation and development strategy of the badminton club of the ordinary university in shaanxi province [D]. Xi 'an sports academy, 2010.

[9]. Chen weidong. The experimental research of the normal university table tennis teaching club. [D].hunan normal university, 2006. 